\title{
Early Onset Pre-Eclampsia with Nephrotic Range Proteinuria as the Initial Manifestation of Lupus Nephritis \\ Report of three cases
}

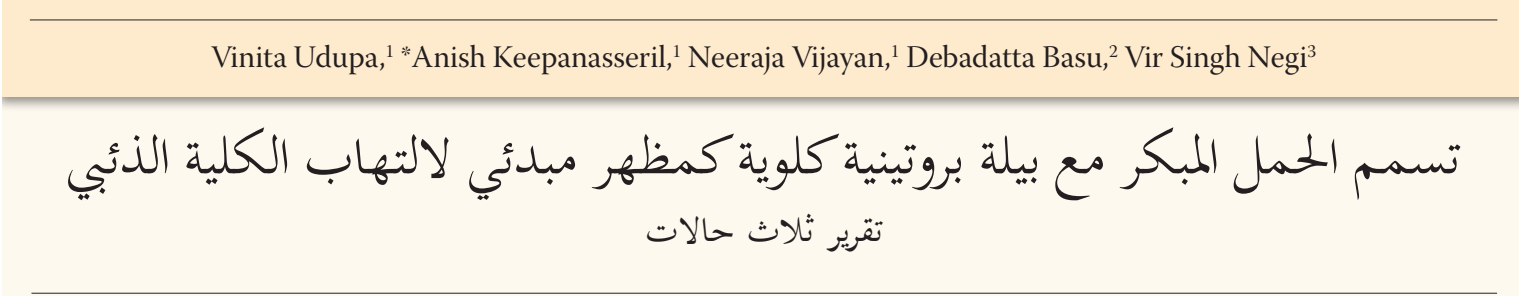

$$
\text { فينيتا أودويا، أنيش كيباناسريل، نيراجا فيجايان، ديباداتًا باسو، فير سينج نيجي }
$$

ABSTRACT: Early onset pre-eclampsia (pre-eclampsia at less than 34 gestational weeks) is a severe form of preeclampsia; in addition, some women may also develop nephrotic range proteinuria. De novo diagnosis of lupus nephritis (LN) in pregnancy is challenging as it may present with features similar to commonly occurring preeclampsia. We report three cases of early onset pre-eclampsia with nephrotic range proteinuria and subsequent diagnosis of LN at the Women and Children hospital attached to Jawaharlal Institute of Postgraduate Medical Education and Research, Puducherry, India, between 2014 and 2017. These cases highlights the need for further evaluation of the association between nephrotic-range proteinuria and early onset pre-eclampsia. The index of suspicion for underlying LN of these type of cases should be high. Earlier detection of LN will prompt better management that can avert or delay short- and long-term morbidity.

Keywords: Lupus Nephritis; Pre-Eclampsia; Nephrotic Syndrome; Proteinuria; Case Reports; India.

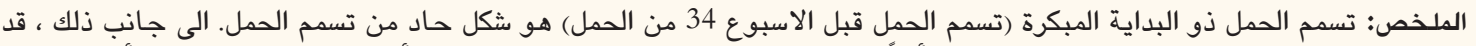

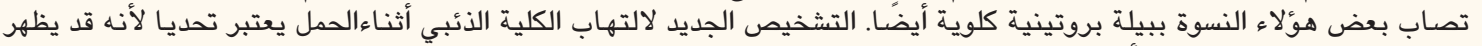

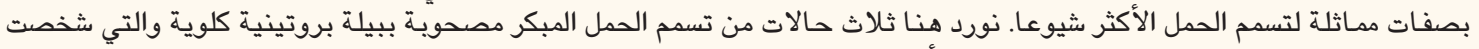

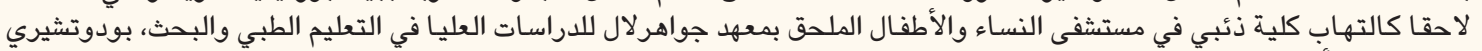

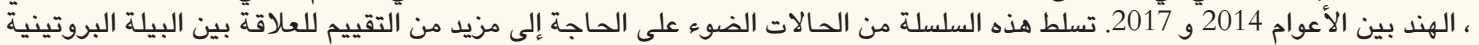

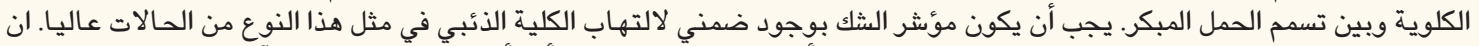

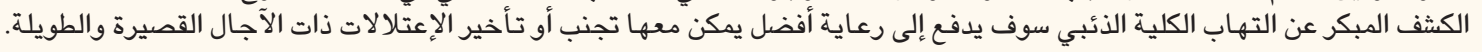

$$
\begin{aligned}
& \text { الكلمات المفتاحية؛ التهاب الكلية الذئبي؛ تسمم الحمل؛ متلازمة كلوية؛ بيلة بروتينية؛ تقارير حالة؛ الهند. }
\end{aligned}
$$

$\mathrm{P}^{\prime}$ RE-ECLAMPSIA IS CHARACTERISED BY ABNORMAL placentation and endothelial dysfunction secondary to an imbalance of angiogenic factors occurring early in pregnancy. Early onset pre-eclampsia that develops before 34 gestational weeks represents a severe form of the hypertensive disorders during pregnancy. The presence of significant proteinuria is regarded as one of the diagnostic criteria distinguishing pre eclampsia from gestational hypertension. ${ }^{1}$ Systemic lupus erythematosus (SLE) is a multi-systemic autoimmune disorder affecting mostly women of child-bearing age. Nearly two-thirds of the women affected have lupus nephritis (LN) and usually have nephrotic-range proteinuria (>3.5 g/day) with active urinary sediments. ${ }^{2,3}$ Preeclampsia occurs in 10-15\% of pregnant women with SLE and is more frequent in those with LN (20-40\%).,5
Women with SLE are reported to have an increased risk of early onset pre-eclampsia. Owing to the similar presentation of pre-eclampsia and $\mathrm{LN}$, it is possible to overestimate this risk due to misclassification of cases. ${ }^{4}$

Nephrotic-range proteinuria complicates $0.32 \%$ of pregnancies, of which pre-eclampsia contributes to $0.19 \% .{ }^{6,7}$ In women with $\mathrm{LN}$ where nephrotic-range proteinuria is a criterion for diagnosis, differentiating new-onset SLE or LN in pregnancy from pre-eclampsia remains a challenge. These cases should be met with a high index of suspicion and require further evaluation with autoantibody screening and a possible renal biopsy for diagnosis. ${ }^{8}$ We report three female patients who presented with early onset pre-eclampsia and nephroticrange proteinuria and were subsequently diagnosed with LN. 
Table 1: Summary of three cases with early onset preeclampsia and lupus nephritis

\begin{tabular}{|c|c|c|c|}
\hline Characteristics & Case 1 & Case 2 & Case 3 \\
\hline Age in years & 26 & 30 & 31 \\
\hline Parity index & G1 & G4, A3 & G2, PL1 \\
\hline $\begin{array}{l}\text { Gestational age } \\
\text { at presentation in } \\
\text { weeks }\end{array}$ & 26 & 30 & 29 \\
\hline $\begin{array}{l}24 \text { hour urinary } \\
\text { protein in } \mathrm{mg} / \\
\text { day }\end{array}$ & 3,540 & 4,020 & 3,800 \\
\hline $\begin{array}{l}\text { Serum albumin } \\
\text { in } \mathrm{mg} / \mathrm{dL}\end{array}$ & 2.1 & 1.9 & 2.3 \\
\hline $\begin{array}{l}\text { Highest serum } \\
\text { creatinine in } \\
\mathrm{mg} / \mathrm{dL}\end{array}$ & 3.4 & 1.9 & 2.1 \\
\hline $\begin{array}{l}\text { Platelet count in } \\
\times 10^{5} / \mathrm{mm}^{3}\end{array}$ & 2.05 & 2.53 & 2.37 \\
\hline $\begin{array}{l}\text { Other obstetric } \\
\text { complication }\end{array}$ & None & None & IUGR \\
\hline Antibody profile & $\begin{array}{c}\text { ANA } \\
\text { positive }\end{array}$ & $\begin{array}{l}\text { ANA and } \\
\text { dsDNA } \\
\text { positive }\end{array}$ & $\begin{array}{l}\text { ANA and } \\
\text { dsDNA } \\
\text { positive }\end{array}$ \\
\hline $\begin{array}{l}\text { Timing of renal } \\
\text { biopsy }\end{array}$ & $\begin{array}{l}\text { Antenatal } \\
\text { (28 gesta- } \\
\text { tional weeks) }\end{array}$ & Postnatal & Postnatal \\
\hline $\begin{array}{l}\text { Renal biopsy } \\
\text { finding }\end{array}$ & $\begin{array}{l}\text { Class-IV } \\
\text { LN }\end{array}$ & $\begin{array}{c}\text { Class-IV-V } \\
\text { LN }\end{array}$ & $\begin{array}{l}\text { Class-IV } \\
\text { LN }\end{array}$ \\
\hline $\begin{array}{l}\text { Treatment } \\
\text { received }\end{array}$ & $\begin{array}{l}\mathrm{HCQ} \text { and } \\
\text { prednisolone }\end{array}$ & $\begin{array}{c}\mathrm{HCQ} \text { and } \\
\text { prednisolone }\end{array}$ & $\begin{array}{l}\mathrm{HCQ} \text { and } \\
\text { prednisolone }\end{array}$ \\
\hline
\end{tabular}

$G=$ gravida $A$ = abortion $P L=$ preterm and living; $I U G R=$ intrauterine growth restriction; $A N A=$ antinuclear antibody; $d S D N A=$ double stranded $D N A ; L N=$ lupus nephritis; HCQ = hydroxychloroquine.

\section{Case Reports}

All three cases presented at Women and Children hospital attached to Jawaharlal Institute of Postgraduate Medical Education and Research, Puducherry, India, between 2014-2017 with early onset of pre-eclampsia between 26 and 30 gestational weeks. All cases had nephroticrange proteinuria and hypoalbuminaemia. Urinary sediments or haematuria were not noted and ultrasound examination showed normal sized kidneys at presentation. None had any clinical symptoms suggestive of any connective tissue disorders. On evaluation, all patients were found to be antinuclear antibody (ANA) positive with low complement levels (C3 and C4). During the antenatal period, all patients were monitored for blood pressure, urine output, renal function and fetal monitoring with ultrasound biometry and non-stress tests [Table 1]. Labour and delivery details were gathered for the three cases [Table 2].

All information was retrieved from medical records without collecting any identifying details, therefore, ethical approval was not sought. However, all patients signed written informed consent forms.
Table 2: Labour and delivery details of three cases with early onset pre-eclampsia and lupus nephritis

\begin{tabular}{lccc} 
Variable & Case 1 & Case 2 & Case 3 \\
$\begin{array}{l}\text { Gestational age at } \\
\text { delivery in weeks* }\end{array}$ & 34 & 33 & 31 \\
$\begin{array}{l}\text { Neonatal outcome } \\
\text { Live } \\
\text { born }\end{array}$ & Live born & Stillborn \\
$\begin{array}{l}\text { Birth weight in g } \\
\begin{array}{l}\text { Apgar score at 5 } \\
\text { minutes }\end{array}\end{array}$ & 9,100 & 1,900 & 980 \\
$\begin{array}{l}\text { Neonatal } \\
\text { complications }\end{array}$ & $\begin{array}{c}\text { Low } \\
\text { birth } \\
\text { weight }\end{array}$ & $\begin{array}{c}\text { Low birth weight } \\
\text { and NICU } \\
\text { admission }\end{array}$ & - \\
\hline
\end{tabular}

$N I C U=$ neonatal intensive care unit

*All labour was induced and mode of delivery was vaginal.

\section{Case One}

A 26-year-old primigravida woman at 26 gestational weeks presented to the emergency obstetric services in 2014 with a maximum blood pressure of 160/100 $\mathrm{mmHg}$ and spot urine protein of 3+; thus, she was diagnosed with early onset pre-eclampsia. She was started on nifedipine $10 \mathrm{mg}$ three times per day. Her laboratory tests revealed raised serum creatinine $(1.7 \mathrm{mg} / \mathrm{dL})$ and 24 hour urinary protein of $3,540 \mathrm{mg} /$ day. In view of her rapidly worsening renal function (highest serum creatinine level was $3.4 \mathrm{mg} / \mathrm{dL}$ ) and nephrotic-range proteinuria, a renal biopsy was performed at 28 gestational weeks which revealed class-IV LN. She was ANA positive and was started on prednisolone (60 mg/day) and hydroxychloroquine (200 mg/day). At the time of delivery, her creatinine levels dropped to $1.4 \mathrm{mg} / \mathrm{dL}$. Labour was induced at 34 gestational weeks in view of the severe early onset pre-eclampsia. She delivered a baby boy weighing 2,100 g with an Apgar score of 9 at 5 minutes. Her post-partum blood pressure returned to normal by the tenth day and her serum creatinine level at discharge was $1.1 \mathrm{mg} / \mathrm{dL}$.

\section{Case Two}

A 30-year-old woman with three previous abortions was referred, to the emergency services in 2015, at 30 gestational weeks with early onset pre-eclampsia. She had a blood pressure of 150/90 $\mathrm{mmHg}$ and spot urine protein of $4+$ on admission and was on nifedipine 30 $\mathrm{mg} /$ day. She was started on prednisolone $40 \mathrm{mg} /$ day in view of suspected LN based on positive ANA and dsDNA results. Her blood pressure remained normal and her creatinine levels were stable $(1.2-1.4 \mathrm{mg} / \mathrm{dL})$. She was induced at 33 gestational weeks with prostaglandin E2 gel and delivered a baby girl weighing 1,900 g with an Apgar score of 9 at 5 minutes. Her blood pressure 
was controlled with nifedipine $30 \mathrm{mg} /$ day. In view of positive autoantibody screening, raised creatinine levels $(1.9 \mathrm{mg} / \mathrm{dL})$ and nephrotic-range proteinuria, a renal biopsy was done in the postnatal period which was reported as class-IV and -V LN. Her creatinine level at discharge on the fourteenth postnatal day was $1.1 \mathrm{mg} / \mathrm{dL}$. At discharge, she was on prednisolone, hydroxychloroquine and nifedipine (60, 200 and $30 \mathrm{mg}$ /day, respectively).

\section{Case Three}

A 31-year-old multiparous woman with chronic hypertension was admitted to the antenatal wards in 2016, at 29 gestational weeks for evaluation of superimposed pre-eclampsia. She was on alpha-methyldopa $250 \mathrm{mg}$ three times a day and to control her high blood pressure, nifedipine $10 \mathrm{mg}$ three times a day was added. Investigations revealed normal liver function, serum creatinine $(1.22 \mathrm{mg} / \mathrm{dL})$, platelet count $\left(2.05 \times 10^{5} / \mathrm{mm}^{3}\right)$ and a normal peripheral smear. Her 24-hour urine protein excretion was 3,800 mg/day. At 30 gestational weeks and 6 days she developed nausea and vomiting and had a blood pressure of 190/110 mmHg. After consulting a neonatologist, a caesarean section was ruled out due to the neonate's growth restriction and prematurity. Labour was induced with misoprostol (prostaglandin E1) and resulted in intrapartum stillbirth. Her autoantibody screen was positive and in view of nephroticrange proteinuria with persistent renal dysfunction (serum creatinine levels: $1.8-2.1 \mathrm{mg} / \mathrm{dL}$ ), a renal biopsy was performed in the postnatal period which revealed class-IV LN.

\section{Discussion}

Pregnancy leads to changes in the immune system and hormonal profile to promote immune tolerance to sustain pregnancy. Diagnosis of new onset SLE presenting as LN during pregnancy is challenging as it simulates the commonly occurring pre-eclampsia during this period. Presence of medical disorders, especially those associated with autoimmune pathology or vasculopathy are considered risk factors of pre-eclampsia; recent studies have reported similarities in pathogenesis of pre-eclampsia and SLE. ${ }^{9-11}$

The elevated levels of interferon- $\alpha$ found in SLE have anti-angiogenic and anti-proliferative properties that lead to endothelial cell dysfunction mimicking the endothelial-milieu as in pre-eclamptic women. ${ }^{12}$ Similar to pre-eclampsia, angiogenic factors like vascular endothelial growth factor and placental growth factor decrease and levels of anti-angiogenic factors such as soluble fms-like tyrosine kinase 1 increase in those with active lupus and LN. ${ }^{13,14}$ Due to a multisystem involvement similar to lupus, pre-eclampsia might represent the initial manifestation of an autoimmune disorder.

Studies have found that pregnant women with SLE have worse manifestations than pregnant women without SLE and due to the hormonal changes and the increase in cytokines during pregnancy this disease may only be diagnosed for the first time during pregnancy.,10 Most women with new-onset SLE are found to have a lower frequency of common symptoms suggestive of lupus at presentation, such as fever, arthritis, arthralgia, alopecia, oral ulcers and/or hypocomplementaemia, compared to those diagnosed in a non-pregnant state.,3 Thrombocytopaenia is reported to occur in $10-40 \%$ of cases of new-onset lupus but in all present cases platelet counts were normal. ${ }^{5}$ However, more women have nephrotic syndrome when diagnosed during pregnancy making it difficult to differentiate from pre-eclampsia, which complicates pregnancy. 2,5

Indications for a renal biopsy in pregnant women include unexplained rapidly progressive renal failure and symptomatic nephrotic syndrome; it may also be used as a guide in managing patients with $\mathrm{LN} .{ }^{15}$ As there is a risk of maternal-fetal morbidity, any procedure is usually deferred until the post-partum period, unless it requires management before delivery. The risk of various complications following a renal biopsy is higher during pregnancy compared to the post-partum period (7\% versus $1 \%) .{ }^{16}$ The presence of a gravid uterus makes it difficult for patients to lie prone so alternative positions, such as sitting upright or lying in the lateral decubitus position, may be preferred. ${ }^{15,16}$ In the current case report, due to rapidly deteriorating renal function, a biopsy was performed at 28 gestational weeks in one case, whereas it was deferred until delivery in the other two.

Miyamoto et al. found eight out of 11 patients diagnosed with new-onset SLE during pregnancy had pre-eclampsia upon initial presentation, while three developed pre-eclampsia after SLE was diagnosed. ${ }^{3}$ All cases except one, who developed SLE post-partum, had preeclampsia detected in the third trimester of pregnancy. Termination of pregnancy for treating pre-eclampsia resulted in premature births in six out of seven cases. Renal haemodynamic changes along with the hormonal changes of pregnancy may accelerate the decline in renal function and worsen hypertension and proteinuria, as was seen in the current case report. Unless the index of suspicion is high, this can be misinterpreted as worsening pre-eclampsia resulting in iatrogenic premature birth, especially if no prenatal or early pregnancy reports of normal renal function are available. Zao et al's study on new-onset SLE in pregnancy observed that two-thirds (68.8\%) of the patients diagn- 
osed in pregnancy had LN; this was a much higher rate than among those who were not pregnant. ${ }^{2}$ Women who developed LN had nephrotic-range proteinuria and low serum albumin levels compared to non-pregnant control cases with SLE. ${ }^{2}$ All three of the current patients who presented with pre-eclampsia had nephroticrange proteinuria and serum hypoalbuminaemia. All current patients had autoantibodies present and underwent a renal biopsy according to the American College of Rheumatology guidelines, two cases during the postnatal period and one case during the antenatal period, confirming the diagnosis of LN. ${ }^{8}$

\section{Conclusion}

The index of suspicion of underlying LN should be high upon presentation of early-onset pre-eclampsia with nephrotic-range proteinuria and hypoalbuminaemia. Autoantibody screening should be performed and if positive, a renal biopsy may be considered. Early detection of LN would lead to better management that can avert or delay short- and long-term morbidity.

\section{References}

1. American College of Obstetricians and Gynecologists; Task Force on Hypertension in Pregnancy. Hypertension in pregnancy. Report of the American College of Obstetricians and Gynecologists' Task Force on Hypertension in Pregnancy. Obstet Gynecol 2013; 122:1122-31. https://doi.org/10.1097/01.AOG.00 00437382.03963 .88 .

2. Zhao C, Zhao J, Huang $\mathrm{Y}$, Wang $\mathrm{Z}$, Wang $\mathrm{H}$, Zhang $\mathrm{H}$, et al. New-onset systemic lupus erythematosus during pregnancy. Clin Rheumatol 2013; 32:815-22. https://doi.org/10.1007/s100 67-013-2180-z.

3. Miyamoto T, Hoshino T, Hayashi N, Oyama R, Okunomiya A, Kitamura S, et al. Preeclampsia as a manifestation of new-onset systemic lupus erythematosus during pregnancy: A case-based literature review. AJP Rep 2016; 6:e62-7. https://doi.org/10.10 55/s-0035-1566245.

4. Simard JF, Arkema EV, Nguyen C, Svenungsson E, Wikström AK, Palmsten K, et al. Early-onset preeclampsia in lupus pregnancy. Paediatr Perinat Epidemiol 2017; 31:29-36. https://doi.org/10.11 11/ppe.12332.
5. Stanhope TJ, White WM, Moder KG, Smyth A, Garovic VD. Obstetric nephrology: Lupus and lupus nephritis in pregnancy. Clin J Am Soc Nephrol 2012; 7:2089-99. https://doi.org/10.22 15/CJN.12441211.

6. Côté AM, Sauvé N. The management challenges of nonpreeclampsia-related nephrotic syndrome in pregnancy. Obstet Med 2011; 4:133-9. https://doi.org/10.1258/om.2011.110001.

7. Brown RA, Kemp GJ, Walkinshaw SA, Howse M. Pregnancies complicated by preeclampsia and non-preeclampsia-related nephrotic range proteinuria. Obstet Med 2013; 6:159-64. https://doi.org/10.1177/1753495X13498382.

8. Hahn BH, McMahon MA, Wilkinson A, Wallace WD, Daikh DI, Fitzgerald JD, et al. American College of Rheumatology guidelines for screening, treatment, and management of lupus nephritis. Arthritis Care Res (Hoboken) 2012; 64:797-808. https://doi.org/1 $0.1002 /$ acr. 21664 .

9. Doria A, Ghirardello A, Iaccarino L, Zampieri S, Punzi L, Tarricone E, et al. Pregnancy, cytokines, and disease activity in systemic lupus erythematosus. Arthritis Rheum 2004; 51:989-95. https://doi.org/1 $0.1002 /$ art.20837.

10. Cudihy D, Lee RV. The pathophysiology of pre-eclampsia: Current clinical concepts. J Obstet Gynaecol 2009; 29:576-82. https://doi.org/10.1080/01443610903061751.

11. Nanjundan P, Bagga R, Kalra JK, Thakur JS, Raveendran A. Risk factors for early onset severe pre-eclampsia and eclampsia among North Indian women. J Obstet Gynaecol 2011; 31:384-9. https://doi.org/10.3109/01443615.2011.566389.

12. Andrade D, Kim M, Blanco LP, Karumanchi SA, Koo GC, Redecha $\mathrm{P}$, et al. Interferon- $\alpha$ and angiogenic dysregulation in pregnant lupus patients who develop preeclampsia. Arthritis Rheumatol 2015; 67:977-87. https://doi.org/10.1002/art.39029.

13. Rhee JS, Young BC, Rana S. Angiogenic factors and renal disease in pregnancy. Case Rep Obstet Gynecol 2011; 2011:281391. https://doi.org/10.1155/2011/281391.

14. de Jesus GR, de Jesus NR, Levy RA, Klumb EM. The use of angiogenic and antiangiogenic factors in the differential diagnosis of pre-eclampsia, antiphospholipid syndrome nephropathy and lupus nephritis. Lupus 2014; 23:1299-301. https://doi.org/10. $1177 / 0961203314529172$

15. Almaani S, Meara A, Rovin BH. Update on lupus nephritis. Clin J Am Soc Nephrol 2017; 12:825-35. https://doi.org/10.2215/ CJN.05780616.

16. Piccoli GB, Daidola G, Attini R, Parisi S, Fassio F, Naretto C, et al. Kidney biopsy in pregnancy: Evidence for counselling? A systematic narrative review. BJOG 2013; 120:412-27. https://doi.org/10. $1111 / 1471-0528.12111$ 